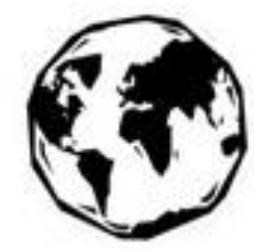

Institute for International Law

Working Paper No. 205 - September 2018

COMMONS, GLOBAL (ECONOMIC) GOVERNANCE AND DEMOCRACY: WHICH WAY FORWARD FOR INTERNATIONAL LAW?

Samuel Cogolati Jan Wouters 


\title{
COMMONS, GLOBAL (ECONOMIC) GOVERNANCE AND DEMOCRACY: WHICH WAY FORWARD FOR INTERNATIONAL LAW?
}

\author{
SAMUEL COGOLATI \\ JAN WOUTERS
}

\begin{abstract}
Since the landmark book Governing the Commons by Nobel Prize winner Elinor Ostrom (1990), the commons represent an alternative governance model to share resources among communities beyond the logics of market and state. Yet, it is too often overlooked that millions of people, mostly living in developing countries, have in fact been depending on commons such as forests, pastures, grazing lands and fisheries to meet their basic needs for far longer. Because these commons are often left unrecognized, they face the threat of enclosure, which risks depriving small-scale farmers, pastoralists, forest-dwellers, artisanal fishers and indigenous peoples in the Global South from their most basic access to food, land, and other essential resources. In the face of this dramatic new wave of enclosure, legal scholars are called upon to rethink the prevailing system of global (economic) governance. The main challenge, it seems, is to halt the seemingly inexorable process of transformation of commons into capital. For that purpose, all legal disciplines, from legal theory, (intellectual) property law to constitutional and administrative law, have contributed to the current debates on the commons. However, surprisingly, very little has been said about the role that international law can play in the empowerment of communities in the self-management of their resources and in the resistance against the dispossession of the commons - notably in the Global South. Whereas global commons like outer space or the high seas are subject to special treaty regimes between states and international legal principles such as the common heritage of mankind, it remains particularly unclear to what extent international law can require states to recognize the commons as a democratic practice of its own and protect marginalized populations from enclosure and dispossession. This working paper asks the question as to whether international law can be part of the solution in saving the commons from enclosure. It starts by explaining why international legal scholars should not confuse the commons with the more familiar notion of 'global commons'. It then makes clear how the current system of global (economic) governance represents a threat to commons worldwide - especially by looking at economic development policies of the World Bank. Finally, it argues that international law could reverse this trend towards the enclosure of the commons by giving due recognition to the social institution of the commons.
\end{abstract}

\section{Keywords}

commons, global (economic) governance, development, World Bank, international law, peasant rights 


\section{Authors}

\section{Samuel Cogolati}

PhD Fellow of the Research Foundation - Flanders (FWO), Leuven Centre for Global Governance Studies and Institute for International Law, KU Leuven.

samuel.cogolati@kuleuven.be

\section{Jan Wouters}

Full Professor of International Law and International Organizations, Jean Monnet Chair ad personam EU and Global Governance and Director, Leuven Centre for Global Governance Studies and Institute for International Law, KU Leuven.

jan.wouters@ggs.kuleuven.be 


\section{COMMONS, GLOBAL (ECONOMIC) GOVERNANCE AND DEMOCRACY: WHICH WAY FORWARD FOR INTERNATIONAL LAW?}

ABSTRACT

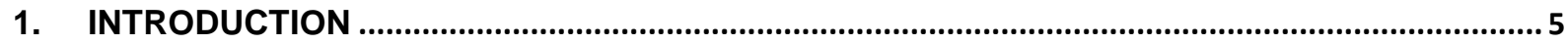

2. THE COMMONS: A NEW NOTION FOR INTERNATIONAL LAW ...............................................

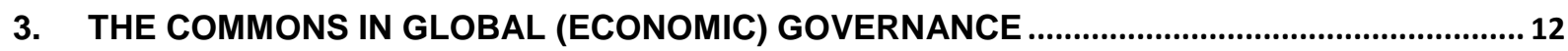

4. INTERNATIONAL LAW TO RECOGNIZE THE COMMONS AS A DEMOCRATIC PRACTICE

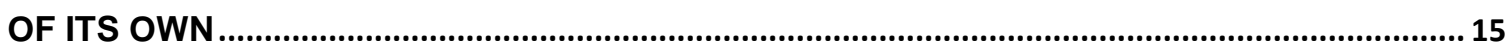

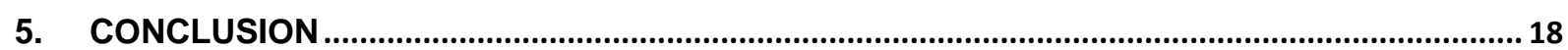




\section{Introduction}

In the Middle Ages the commons used to be pastures and woodlands that, by custom, could be accessed and jointly managed by communities of villagers. The commons were brought back to the attention of the scientific community by the popular article of the American scientist Garrett Hardin in 1968: 'The Tragedy of the Commons'. ${ }^{1}$ Hardin described an economic model - devoid of any empirical evidence but based on rational choice theory - in which individual actors automatically tend to over-exploit and plunder common-pool resources (CPRs) that are freely available to everyone. It was widely admitted that the twin features of CPRs, namely their difficulty to exclude and the rivalrous nature of the goods they either contained or produced, would lead to a collective action problem akin to the prisoner's dilemma. ${ }^{2}$ Hardin's prediction of no cooperation is entirely consistent with this inexorable dilemma. Hardin illustrates this with the example of an open-access pasture on which self-interested herders use as much grass as possible to rear their cattle. The commoners, assumed to be rational, incommunicative and selfish agents, are locked into short-term strategies and keep subtracting as much as possible from what Hardin mistakenly termed the 'commons'. The inevitable result is their degradation and depletion. According to Hardin, '[f]reedom in a commons brings ruin to all'. ${ }^{3}$ To avoid the unconstrained over-exploitation of natural resources by selfish individuals, Hardin only believes in two possible coercive arrangements: the enclosure of resources through private property, or, failing that, public regulation. ${ }^{4}$ Even though he admits that the legal institution of private property is 'unjust', he claims that there is no 'better system': ' $[\mathrm{t}] \mathrm{he}$ alternative of the commons is too horrifying to contemplate. ${ }^{5}$

Despite the influence up until today of Garrett Hardin's narrative in mainstream political discourse, the story did not stop there. In her landmark book Governing the Commons, Elinor Ostrom showed through various case studies how local communities could develop autonomous institutions with their own ad hoc rules to govern the resource domains upon which they depend for their subsistence. ${ }^{6}$ Her book soon became the standard reference in the study of the commons, as it examined the factors that lead self-governance mechanisms to succeed - Swiss Alpine pastures, irrigation systems in Spain, Turkish or Sri Lankan fisheries. Commons have indeed existed over long periods of time and one of the reasons for their long-enduring success is that commoners do not always act as homines economici. Commoners are social actors embedded in tight-knit communities that communicate, observe social norms and judge their fellow members on the basis of their reputation. Consequently, commoners are capable of collectively making some binding decisions that supply institutions, limit their individual consumption and preserve their resource domains in the long run. Despite the wide diversity of local arrangements, Ostrom identifies eight 'design principles' for commons-based institutions that characterize sustainable institutions for collective action in the long term, among which clearly defined jurisdictional boundaries, clear rules of access and use, conflict-resolution mechanisms that foster mutual trust, and sanctions to deter free-riders. ${ }^{7}$ In brief, in exploring the empirical realities behind the management of CPRs, Ostrom rebutted Hardin's assumption that commons equate open access regimes. She proved that it was possible to prevent commons from collapsing through institutions that are neither 'all-private', nor 'all-public', but collectively owned. She convincingly showed that the pessimistic scenario set out by the prisoner's dilemma was misleading.

\footnotetext{
1 Garrett Hardin, 'The Tragedy of the Commons' (1968) 162(3859) Science 1243.

2 Mancur Olson, The Logic of Collective Action. Public Goods and the Theory of Groups (Harvard University Press 1965).

${ }^{3}$ Hardin, supra n 1, 1244.

${ }^{4}$ Hardin, supra $\mathrm{n} 1,1247$.

${ }^{5}$ Hardin, supra n 1, 1247.

${ }^{6}$ Elinor Ostrom, Governing the Commons: The Evolution of Institutions for Collective Action (CUP 1990).

7 ibid, 90.
} 
Since the award of the Nobel Prize in Economic Science to Elinor Ostrom in 2009, the commons as an alternative model of governance beyond market and State has been given worldwide exposure. Ostrom's acceptance speech on that occasion, entitled 'Beyond Markets and States: Polycentric Governance of Complex Economic Systems', summarized neatly her lifelong effort to unearth the regulating principles and the institutional architecture that accounted for the success of innovative modes of decentralized and bottom-up governance, beyond the much travelled paths of the exclusively public or exclusively private management solutions. ${ }^{8}$ Her pioneering research, based on extensive fieldwork and relying on three decades spent refining her 'Institutional Analysis and Development' (IAD) framework, looks into the previously underestimated achievements of regimes of self-organization at all levels of governance. Her central claim turned conventional wisdom upside down: complex socioecological systems (in which goods are subtractable and beneficiaries are hard to exclude) can prove to be sustainable resource domains granted that its stakeholders adopt a polycentric and self-regulated mode of governance.

Since her Nobel Prize in 2009, many researchers have adopted Ostrom's IAD framework to scrutinize the governance of CPRs, be they natural or subsistence commons, or more groundbreaking such as knowledge or cultural commons. There have been innumerable case studies assessing the robustness of the governance models suggested by Ostrom and refining her findings. Ostrom's design principles have been applied in very different contexts, beyond the sole issue of natural resource management. Her work opened the eyes of many academics to the fact that CPRs were not doomed to a tragic fate unless they were either enclosed and commercialized or turned into public property and administered by the State. Seen in this light, the commons have been burdened by some authors with the responsibility of carving out an autonomous social space independent from both the atomization of capitalist markets and the hierarchical structure of the State. Moreover, the commons have been embraced by civil society and social activists as a new direct form of democratic governance to rethink the traditional public-private and market-State divides, and to prioritize ecological and human needs of communities. ${ }^{9}$

The commons are nowadays on everyone's lips. New commons like cohousing initiatives, community gardening, community land trusts, and open-source media like Wikipedia, are burgeoning all across the world. Yet, it is too often overlooked that millions of people, mostly living in developing countries, have in fact been depending on commons such as forests, pastures, grazing lands and fisheries to meet their basic needs for far longer. ${ }^{10}$ Because these commons are often left unrecognized, they face the threat of enclosure, which risks depriving small-scale farmers, pastoralists, forest-dwellers, artisanal fishers and indigenous peoples in the Global South, from their most basic access to food, land, and other essential resources. This trend extends beyond the so-called 'global land grab', ${ }^{11}$ and includes the commodification of many other natural resources in developing countries. One may think of concessions for land mining in Peru or Colombia ${ }^{12}$ and the privatization of water cooperatives in Bolivia, ${ }^{13}$ which disrupt the communal self-organization of local populations. This movement is led by State and

\footnotetext{
8 Elinor Ostrom, 'Beyond Markets and States: Polycentric Governance of Complex Economic Systems' (8 December 2009) <https://www.nobelprize.org/nobel_prizes/economicsciences/laureates/2009/ostrom_lecture.pdf> accessed 7 August 2018.

${ }^{9}$ David Bollier and Silke Helfrich (eds), The Wealth of the Commons: A World Beyond Market and State (Levellers Press 2012).

10 Oxfam, International Land Coalition, Rights and Resources Initiative, Common Ground. Securing Land Rights and Safeguarding the Earth (Oxfam 2016).

11 Liz Alden Wily, 'The Global Land Grab: The New Enclosures' in David Bollier and Silke Helfrich (eds), The Wealth of the Commons: A World Beyond Market \& State (Levellers Press 2012) 132-140; Smita Narula, 'The Global Land Rush: Markets, Rights, and the Politics of Food' (2013) 49(1) Stan J Int'I L 101.

${ }^{12}$ César Padilla, 'Mining as a Threat to the Commons: the Case of South America' in David Bollier and Silke Helfrich (eds), The Wealth of the Commons: A World Beyond Market \& State (Levellers Press 2012) 157-160.

13 Manuel de la Fuente, 'A Personal View: The Water War in Cochabamba, Bolivia: Privatization Triggers an Uprising' (2003) 23(1) Mt Res Dev 98.
} 
private investors - both domestic and foreign -, but it is also facilitated by the dominant system of global (economic) governance based on competition and wealth maximization.

In the face of this dramatic 'new wave of "enclosing the commons"', ${ }^{14}$ international legal scholars are called upon to rethink the prevailing system of global (economic) governance and the central role of the sovereign State in the Western legal culture. The commons have already caused much ink to flow in the legal literature. At the domestic level, legal scholars have devised new legal tools, like collective property regimes and public trust doctrines. Some authors have even attempted to reframe the commons as a legal concept of its own. ${ }^{15}$ The main challenge, it seems, is to halt the seemingly inexorable process of transformation of commons into capital. For that purpose, all legal disciplines, from legal theory, (intellectual) property law to constitutional and administrative law, have contributed to the current debates on the commons. However, surprisingly little has been said about the role that international law can play in the empowerment of communities in the self-management of their resources and in the resistance against the dispossession of the commons - notably in the Global South. Whereas global commons like outer space or the high seas are subject to special treaty regimes between States and are governed by international legal principles such as the common heritage of mankind, it remains particularly unclear if the commons exist as a social institution in the realm of international law.

Our main endeavour throughout this contribution will be to assess to what extent international law can require States to recognize this polycentric and self-regulated mode of governance and protect marginalized populations from enclosure and dispossession of their commons in the context of global (economic) governance. We start by defining what we understand by the notion of 'commons' and we underline why international legal scholars should not confuse it with the more familiar notion of 'global commons' (Section 2). We then make clear how the current system of global (economic) governance represents a threat to commons worldwide especially by looking at economic development policies of the World Bank (Section 3). Finally, we argue that international law could reverse this trend towards the enclosure of the commons by giving due recognition to the social institution of the commons. Even if this countermovement in international law is still in its infancy, the project of a United Nations (UN) declaration on rights of peasants now contains a standalone obligation for States to protect the commons and their related systems of collective use and management (Section 4). We conclude that in this sense, international law could serve as a strategic instrument in the recognition and protection of the commons as a democratic practice of its own.

\section{The commons: a new notion for international law}

Far from being a monolithic notion, the commons today evoke a wealth of - sometimes contradictory - meanings. This is also the case in the literature. Whereas some authors focus on well-defined resource domains at the local or global levels, others insist that the commons are primarily about social and political movements against the top-down logic of market and States. While this diversity should be acknowledged as it is inherent in the multifaceted nature of the commons as a new social imaginary, it also poses a dilemma for international law.

To try to define the notion of the 'commons', authors often resort first to the traditional classification of goods in economic theory. Contrary to public goods which are non-rival, CPRs are rival in consumption, and therefore vulnerable for depletion. However, today, the commons do no longer exclusively refer to tangible CPRs like pastures, seeds, forests or water reserves,

\footnotetext{
14 David Harvey, The New Imperialism (OUP 2003), 148.

15 Maria Rosaria Marella, 'The Commons as a Legal Concept' (2017) 28(1) Law \& Crit 61; Ugo Mattei and Alessandra Quarta, 'Principles of Legal Commoning' (2017) 49(1) Revue juridique de l'environnement 67.
} 
but also to intangibles resources such as the internet, software codes and human genes. In fact, the latter - often termed as 'knowledge commons' or 'informational commons' - are different because they are often non-rival (if not abundant) and easily reproducible. This is why the commons have become more closely connected with the collective self-governance and collaborative mechanisms they imply, than with the strict category of (rivalrous and nonexcludable) economic goods they once referred to. In other words, the commons can no longer be abstracted from the social networks that participate in their production and protection: without communities, no commons. In this contribution, we also move away from the naturalistic view of the commons as CPRs, and adopt a more sociologic approach. We do not simply speak of common goods in this contribution. Instead, we define the commons in an open way, as a social system consisting of at least three cumulative elements:

(i) A common-pool resource, be it tangible natural resources like pastures, lands, seeds, forests or water reserves, or intangible resources such as traditional knowledge or the internet (the object);

(ii) A community (a family, a village, a tribe, etc.) that has exclusive (no free and open) access to the resource in question and that manages it in common (the subject);

(iii) The practice of commoning, that is the concrete activity of governing a resource through collective action and according to ad hoc rules (no public or private property) (the practice).

The rules constitutive of the practice of commoning are specific to each commons. It is therefore impossible to apply a unique and closed definition of the commons. It is rather in a very broad and plural sense, as an 'institution for collective action', ${ }^{16}$ that the commons are understood in this contribution. The commons represent grassroots institutions developed by communities, thereby creating a space of self-government beyond market and State, to share and govern resources in a horizontal and autonomous fashion. It is this institutional and social element for self-government which makes the commons so different from privately or publicly owned resources. It is also this institutional and social element which is mostly absent in international law and therefore calls for further study.

So, what is 'new' in this for international legal scholars? When it comes to the governance of the commons at the interstate level, the latter immediately think of 'global commons'. Global commons stricto sensu depict under international law physical resources which lie outside of the control of any State - that is beyond territories subject to the sovereign jurisdiction of a State. International law typically recognizes the following global commons: the high seas, the deep seabed, outer space, the Moon and other celestial bodies, as well as Antarctica. ${ }^{17}$ Those global commons do not belong to any of the 193 UN Member States, nor are they in principle subject to national appropriation. As the UN Environment Programme (UNEP) stresses, '[d]espite efforts by governments or individuals to establish property rights or other forms of control over most natural resources, the Global Commons have remained an exception'. ${ }^{18}$ More recently, the atmosphere has also been qualified as a global commons sensu lato since air pollution knows no borders. ${ }^{19}$ Its management under international law indeed presents the same problems of collective action and free-riding as traditional global commons: one could

\footnotetext{
16 Tine De Moor, 'From common pastures to global commons: a historical perspective on interdisciplinary approaches to commons' (2011) 19(4) Natures Sciences Sociétés 422.

17 Antarctic Treaty (1 December 1959) 402 UNTS 71. Pursuant to Article IV(2), the Treaty suspended all existing and precluded new claims of States to territorial jurisdiction over parts of the South Pole. Antarctica is designated 'as a natural reserve, devoted to peace and science'.

18 United Nations 'Global Program, Commons' <http://staging.unep.org/delc/GlobalCommons/tabid/54404/Default.aspx> accessed 17 May 2018.

${ }^{19}$ See, e.g., Nico Schrijver and Vid Prislan, 'From Mare Liberum to the Global Commons: Building on the Grotian Heritage' (2009) 30 Grotiana 168, 196.
} 
think, for instance, of the depletion of the ozone layer. ${ }^{20}$ This is how more recently the concept of global commons also came to include 'common concerns of humankind' such as biodiversity conservation $^{21}$ and climate change..$^{22}$

However, international legal scholars seem so familiar with the notion of 'global commons' that they generally tend to conflate it with the social institution of the 'commons'. ${ }^{23}$ As Burns Weston and David Bollier show, however, the category of global commons 'tends to be more aspirational than juridical at this point in history, and thus be thought of as CPRs in need of governance structure'. ${ }^{24}$ It should indeed be emphasized that the high seas, outer space or Antarctica have never been truly managed as commons: 'such planetary resources remain [CPRs], not commons, until they are subject to a viable governance regime that benefits all relevant commoners and draws upon their participatory "communing" practices. ${ }^{25}$ This terminological confusion between 'commons 'and 'global commons' is probably less likely to arise in French, where the notions of 'patrimoine commun de l'humanité' or 'biens communs mondiaux' more clearly point to resource-domains ('patrimoine'; 'biens') and less so to the bottom-up system of governance of the commons. In any case, we argue against the amalgamation for at least two substantive reasons.

First, the idea of res communis (omnium) (common ownership for everyone) that underlies the international law notion of global commons entails different legal connotations than the social institution of the commons. The first coherent articulation of the concept of res communis in international law is to be found in the texts of natural law thinkers like Francisco de Vitoria and Hugo Grotius, who sought to justify the colonial expansion of European powers and, as a corollary, the enclosure of the 'commons' in the New World. As Olivier De Schutter notes, '[t]he idea that the territories to be "civilized" and converted to Christianism were functioning as a "commons", in which land was neither subject to property rights nor controlled by a political sovereign deserving to be called a "State" (since the control over a territory was seen as a defining characteristic of State sovereignty), was central to this project.'26 De Vitoria (14861546) only used the concept of res communis instrumentally, to depict something that belonged to everyone and therefore remained free for appropriation by conquistadores. He did not touch upon the question as to how 'the Indians' had been depending on those lands for centuries, or not even how the medieval commons had been organizing social life in Europe. In the end, de Vitoria's idea of res communis only served to legitimize the enclosure of what we today call 'commons' - not directly through territorial annexations by powerful States, but, as Koskenniemi notes, through a more 'informal [type of] imperial domination that is achieved through a worldwide pattern of acquisition and exchange of private property by which [...]

\footnotetext{
${ }^{20}$ See, e.g., Montreal Protocol on Substances that Deplete the Ozone Layer (adopted 16 September 1987 ) 1522 UNTS 3.

21 See Convention on Biological Diversity (CBD) (5 June 1992) 1760 UNTS 79, preamble, para. 3.

22 See United Nations Framework Convention on Climate Change (UNFCCC) (9 May 1992) 1771 UNTS 107, preamble, para. 1; Paris Agreement (12 December 2015) UN Doc FCCC/CP/2015/L.9, preamble, para. 11.

${ }^{23}$ See, e.g., Surabhi Ranganathan, 'Global Commons' (2016) 27(3) European Journal of International Law 693. Ranganathan considers at p. 695 and p. 714 that both Hardin's tragedy of the commons and international law concept of common heritage of mankind are two 'comprehensive imaginaries of the commons' and 'address the same subject - commons'. A similar lack of terminological accuracy can be found in official documents. So, for instance, the Brundtland Report, famous for introducing and defining the concept of sustainable development, devotes an entire chapter to 'Managing the Commons'. Even if the Report uses both terms of 'commons' and 'global commons' interchangeably, in reality, it only refers at p. 216 to 'those parts of the planet that fall outside national jurisdictions' - that is, 'the oceans, outer space, and Antarctica'. See World Commission on Environment and Development (WCED), Report of the World Commission on Environment and Development: Our Common Future (1982) <http://www.un-documents.net/our-common-future.pdf> (accessed 13 July 2018) Chapter 10.

${ }^{24}$ Burns H Weston and David Bollier, Green Governance: Ecological Survival, Human Rights, and the Law of the Commons (CUP 2013) 126.

25 ibid, 129, at footnote 11.

${ }^{26}$ Olivier De Schutter, 'From Eroding to Enabling the Commons: The Dual Movement in International Law' in Samuel Cogolati and Jan Wouters (eds.), The Commons and a New Global Governance (Edward Elgar 2018) x (emphasis added).
} 
formal State policies are also controlled, enabled, or undermined, as befits the global market.' ${ }^{27}$ Building upon de Vitoria's analysis, the international law doctrine of res communis was further developed in the seminal work of Hugo Grotius (1583-1645). At the time, several States like Portugal $^{28}$ and Spain $^{29}$ invoked sovereignty and exclusive access over the Atlantic and the Indian oceans, which prevented the Dutch East India Company to travel the seas as it wished. ${ }^{30}$ Grotius skilfully refuted those claims by resorting to the concept of res communis to reserve those waters for every nation. The seas could not be occupied and therefore belong to everyone ('Mare Liberum').

Even though the Grotian heritage of res communis has later been restrained by the expansion of State sovereignty over global commons and complemented with other duties of conservation, it should not be too quickly dismissed as a relic of a bygone era. 400 years later, it remains central to the governance of global commons under international law, from the high seas $^{31}$ to outer space. ${ }^{32}$ However, the idea of res communis is radically different from the commons understood as an institution for the management of shared resources. On the one hand, the assumed inexhaustibility of res communes, as depicted in the work of early international legal scholars, has nothing to do with the intrinsic rivalry of CPRs which are at the centre of commons-based institutions. The very idea of establishing a commons - from premodern English pastures to the communal governance of indigenous lands in Africa or SouthAmerica - is instead triggered by the need to sustain a resource over the long term. On the other hand, even if the free-for-all exploitation of res communes resembles Hardin's parable of unregulated commons, it is diametrically opposed to the complex rules of access and use established by communities themselves and aimed at the preservation of CPRs. As the International Court of Justice noted in the 1974 Fisheries Jurisdiction cases, the freedom of fishing in the high seas - which was slightly amended in the 1982 Convention - was essentially a regime of 'laissez faire'. ${ }^{33}$ As Nico Schrijver and Prislan state, Grotius's idea of Mare Liberum 'digressed into "first come, first served" advantages for industrialized nations'. ${ }^{34}$ To cut a long story short, open access to ' $\mathrm{global}$ commons' and sustainable self-management of 'commons' are two different things.

Second, even the more recent principle of common heritage of mankind which nowadays governs some global commons under international law ${ }^{35}$ is quite remote from the social

\footnotetext{
27 ibid.

${ }^{28}$ Portugal had claimed sovereignty over the Indian Ocean and the Atlantic Ocean south of Morocco.

${ }^{29}$ Spain had claimed sovereignty over the Pacific Ocean and the Gulf of Mexico.

${ }^{30}$ Fritjof Capra and Ugo Mattei, The Ecology of Law. Toward a Legal System in Tune with Nature and Community (Berrett-Koelher Publishers 2015) 83.

31 United Nations Convention on the Law of the Sea (1982), 1833 UNTS 3: '[t]he high seas are open to all States, whether coastal or land-locked' (Article $87(1)$ ) and '[n]o State shall claim or exercise sovereignty or sovereign rights over any part of [the deep sea bed] or its resources' (Article 137(1)).

32 Treaty on Principles Governing the Activities of States in the Exploration and Use of Outer Space, including the Moon and Other Celestial Bodies (adopted 27 January 1967), 610 UNTS 205: 'Outer space, including the Moon and other celestial bodies, shall be free for exploration and use by all States without discrimination of any kind, on a basis of equality and in accordance with international law, and there shall be free access to all areas of celestial bodies' (Article I(2)).

${ }_{33}$ Fisheries Jurisdiction cases (United Kingdom v. Iceland; Federal Republic of Germany v. Iceland), Merits, Judgments of 25 July 1974, ICJ Reports 1974, p. 3, para. 72, and ICJ Reports 1974, p. 175, para. 64.

34 Nico Schrijver and Vid Prislan, 'From Mare Liberum to the Global Commons: Building on the Grotian Heritage' (2009) 30 Grotiana 168, 206.

${ }^{35}$ Article I(1) of the Treaty on Principles Governing the Activities of States in the Exploration and Use of Outer Space, including the Moon and Other Celestial Bodies (adopted 27 January 1967), 610 UNTS 205: '[t]he exploration and use of outer space, including the Moon and other celestial bodies, shall be carried out for the benefit and in the interests of all countries, irrespective of their degree of economic or scientific development, and shall be the province of all mankind'; Article XI(1) of the Agreement Governing the Activities of States on the Moon and Other Celestial Bodies (adopted 5 December 1979), 1363 UNTS 3: '[t]he Moon and its natural resources are the common heritage of mankind'; Article 136 of the United Nations Convention on the Law of the Sea (adopted 10 December 1982), 1833 UNTS 397: '[t]he Area' - defined as 'the seabed and ocean floor and subsoil thereof, beyond the limits of national jurisdiction' (Article 1(1)(1)) - and 'its resources' - meaning all solid, liquid or gaseous mineral resources
} 
institution of the commons. The principle of common heritage of mankind emerged in the middle of post-colonial efforts to do away with the logic of unbridled exploitation of global commons by Western powers. The first mention of the term 'common heritage of mankind' is generally attributed to Arvid Pardo (1914-1999), Malta's permanent representative to the UN, in a declaration made in November 1967 to the First Committee of the General Assembly, on the seabed and ocean floor beyond the limits of national jurisdiction. ${ }^{36}$ Pardo's speech was a significant event that is commented upon in almost any legal discussion of the common heritage of mankind. Pardo's main concerns seem to have been the risk that 'technologically advanced States [...] appropriate the sea-bed and the ocean floor beyond the 200-metre isobaths for their own use' and the need for environmental preservation of the 'dark oceans [which] are the womb of life' (sic). ${ }^{37}$ In contrast to the logic of laissez-faire of the freedom of the high seas, but also the expanding claims to State sovereignty over the oceans of this time, Pardo's project was to subject the seabed and its resources to international administration and management. This is why the principle of common heritage sparked some enthusiasm among proponents of the commons framework, who saw it as 'the only current alternative to either freedom of use by all States or the acquisition and exercise of sovereign rights'. ${ }^{38}$ This principle indeed reflects the cosmopolitan idea under international law of an interdependent world that should be peacefully managed by all nations and transmitted to future generations. It also articulates key components of sustainability, which of course resemble the commons' concern to preserve CPRs. However, we argue that there remain significant differences between common heritage and commons. To start with, the principle of common heritage, and in particular its core element of non-appropriation, has never been applied to areas within national jurisdiction, not even to those which are said to be globally relevant, such as rainforests or lakes and their flora and fauna. This is allegedly due to the 'fear of infringements on national sovereignty'. ${ }^{39}$ Regardless of what commentators may say about the potential of the principle of the common heritage of mankind to protect common goods, most commons in the world are today simply not subject to it. Even if common heritage cannot be owned, it still can be used by anyone. As Surabhi Ranganathan phrases it, free access becomes a normative principle with common heritage. ${ }^{40}$ This is different in a commons, which is by definition subject to strict rules of access and use defined by the community itself.

To sum up, as the doctrines of res communis and common heritage of mankind illustrate, the international law notion of global commons cannot amount to an extension of the commons in the domain of interstate relations. As Tine De Moor noted, global commons 'lack two important attributes that are characteristic of the commons as they have existed for centuries in Europe and beyond': 'institutionalization and self-governance'. ${ }^{41}$ This shows that scale matters, ${ }^{42}$ also from an international legal perspective. The analogy under international law between the two terms of the commons and global commons reduces the social institution of the commons to an empty space made accessible for unrestricted exploitation and dispossession. The categories of res communis and common heritage have not only failed to protect the commons

in situ in the Area at or beneath the seabed, including polymetallic nodules' (Article 133(b)) -the 'common heritage of mankind'.

36 UN General Assembly, First Committee $1515^{\text {th }}$ Meeting (1 November 1967) UN Doc. A/C.1/PV.1515-1516.

37 UN General Assembly, First Committee 1515 $5^{\text {th }}$ Meeting (1 November 1967) UN Doc. A/C.1/PV.1515-1516, paras 64 and 7.

${ }^{38}$ Prue Taylor, 'The Common Heritage of Mankind: A Bold Doctrine Kept Within Strict Boundaries' in David Bollier and Silke Helfrich (eds), The Wealth of the Commons: A World Beyond Market and State (Levellers Press, 2012) 358.

${ }^{39}$ Nico Schrijver, 'Managing the global commons: common good or common sink' (2016) 27(7) Third World Quart $1252,1258$.

40 Surabhi Ranganathan, 'Global Commons' (2016) 27(3) European Journal of International Law 693, 694.

41 De Moor, supra n 16.

42 Fikret Berkes, 'From Community-Based Resource Management to Complex Systems: The Scale Issue and Marine Commons' (2006) 11(1) Ecology and Society 45. 
as a social institution of its own; they have lent themselves to legitimate the enclosure of the commons.

\section{The commons in global (economic) governance}

The enclosure of the commons is not an isolated phenomenon; it is a systemic issue today taking place in the broader context of global (economic) governance. The current system of global (economic) governance favoured by industrialized countries and grounded in growth and wealth maximization indeed represents a threat to the commons around the world. This is not new. The present model of global (economic) governance has already been called into question by commons activists and scholars. Fritjof Capra and Ugo Mattei, for instance, vigorously denounce the 'idea of "development"' as 'fundamentally quantitative' and 'rooted in seventeenth-century notions of "improvement"', which fails to recognize 'that unrestrained extraction and exploitation of natural and human resources is at odds with the fundamental principles of ecology'. ${ }^{43}$ In the same vein, David Bollier proposes to 'abandon the whole mindset of "development" itself' and, instead, to start talking about 'human flourishing'. ${ }^{44}$ Dirk Löhr suggests that '[i]f community interests in shared natural resources are to survive, a new development agenda will need to be advanced, and it will need to sail against the wind'. ${ }^{45}$

This critique should be taken seriously. Economists and lawyers have traditionally assumed that, without private property, rational self-interested individuals have no incentive to protect their resources and accumulate wealth. ${ }^{46}$ This postulate finds its origins in the classic Coase theorem, which views private ownership as the best way of minimizing externalities and ensuring the best allocation of resources. ${ }^{47}$ This negative depiction of collective ownership was confirmed in the aforementioned article 'The Tragedy of the Commons' by Garrett Hardin. ${ }^{48}$ Hardin argued that commons would automatically be depleted because individuals are only guided by their self-interest to grab what they can before the others destroy the shared resource. Under this pessimistic approach, the commons are basically unregulated and therefore seen as no man's land. Customarily owned lands are considered unowned and unoccupied. This is why development policy-makers rarely go beyond the public-private and State-market dichotomies ${ }^{49}$ and often consider local forms of communal ownership as 'archaic and in need of modernization via privatization and market integration' ${ }^{50}$ In The Mystery of Capital Hernando de Soto famously writes that, whereas in developed countries like the United States land can be used for credit and sold in secondary markets, land in many developing countries is 'dead capital'. ${ }^{51}$ As a critical commentator notes, development strategies are based upon the idea that 'informal, collective forms of property rights should be converted into private

\footnotetext{
${ }^{43}$ Capra \& Mattei, supra n 30, 9.

44 David Bollier, 'Beyond Development: The Commons as a New/Old Paradigm of Human Flourishing' (25 June 2016) <http://www.bollier.org/blog/beyond-development-commons-newold-paradigm-human-flourishing> ${ }^{45}$ Dirk Löhr, 'The Failure of Land Privatization: On the Need for New Development Policies' in David Bollier and Silke Helfrich (eds), The Wealth of the Commons: A World Beyond Market \& State (Levellers Press 2012).

${ }^{46}$ Gershon Feder and David Feeny, 'Land Tenure and Property Rights: Theory and Implications for Development Policy' (1991) 5(1) World Bank Econ Rev 135; Daniel Fitzpatrick, 'Evolution and Chaos in Property Rights Systems: The Third World Tragedy of Contested Access' (2006) 115(5) Yale Law J 996.

47 Ronald Coase, 'The Problem of Social Cost' (1960) 3 J Law \& Econ 1.

48 Hardin, supra $\mathrm{n} 1$.

49 Ioannis Glinavos, 'Transition or development? Reassessing priorities for law reform' (2010) 10(1) Progress in Development Studies 59, 72.

50 Ismael Vaccaro, Laura C Zanotti, Jennifer Sepez, 'Commons and Markets: Opportunities for Development of Local Sustainability' (2009) 18(4) Env Pol 522, 523.

51 Hernando de Soto, The Mystery of Capital: Why Capitalism Triumphs in the West and Fails Everywhere Else (Basic Books 2000) 7.
} 
property because such policies will help ease land conflicts, enhance the efficiency of the land markets, guarantee tenure security and assure access to loans'. ${ }^{52}$

This negative view of the commons is reflected in the development policies of the World Bank - a major actor of global (economic) governance with near universal membership. Since the 1970 s, the institution is well-known as a fierce defender of privatization strategies in 'structural adjustment programmes' (SAPs) ${ }^{53}$ which coerce developing countries to convert untitled lands like the commons into private property on the markets. In a 1975 land policy reform paper, the Bank went so far as to advocate the abandonment of so-called 'backward' customary tenure arrangements and the subdivision of the commons into plots over which 'modern' freehold titles would be granted. ${ }^{54}$ Enforcement of property rights became a desirable standard economic reform supported by the Bank, in what was termed the 'Washington Consensus'. In the 1990s, the Bank further established this policy in helping post-Soviet States to make the transition from State to private ownership of lands and services. This strategy was aimed at facilitating the integration of developing and post-Soviet countries into the world economy and the global supply chains of agricultural commodities. The Bank's land and agricultural policies, prescribed as conditionalities, were directed at securing land tenure and transferability of private property rights through 'free' land markets, at the expense of informal and customary institutions governing communal rights of use. Under this market-based approach, the role of the State was reduced to protecting and enforcing private rights to property, in order to create an enabling environment for economic growth.

The Bank has demonstrated more openness for the commons in a 2003 comprehensive report on its Land Policies for Growth and Poverty Reduction. ${ }^{55}$ It acknowledges therein that '[f]orests and other common property resources contribute significantly to people's welfare, especially of the poor'56 and that 'in most situations simply introducing private property rights will be neither feasible nor cost-effective'. ${ }^{57}$ However, even though the Bank recognizes customary rights, the institution of the commons as such is not regarded as an optimal solution. On the contrary, the 2003 report recommends formalizing customary rights to integrate them 'into more formal systems' ${ }^{58}$ Ultimately, individual ownership is still considered to be 'the arrangement that provides the greatest incentives for efficient resource use'. ${ }^{59}$ Commons are said to be warranted primarily in situations with 'limited economic development'. ${ }^{60}$ As a land expert commented on this report, "[w]hile it is significant that the Bank has recognized the need to respect customary rights, it nevertheless sees individualistic rights of ownership of land as those which represent the most "modern" form of landholding'. ${ }^{61}$

The process of 'modernization' promoted by the Bank and other global (economic) governance actors, based on a conception of individual private property imported from the West, to 'secure' the rights of communities and preventing conflicts over land and other natural resources, is likely to fail. ${ }^{62}$ In most developing countries, the commons are, in practice, already recognized

\footnotetext{
52 Dirk Löhr, 'The Failure of Land Privatization: On the Need for New Development Policies' in David Bollier and Silke Helfrich (eds), The Wealth of the Commons: A World Beyond Market \& State (Levellers Press 2012).

53 SAPs consist of loans to debt-strapped governments, conditioned upon the achievement of a number of policy reforms, among which privatization of government-held enterprises, liberalization of public services and greater efficiency of the free market. The term 'SAP' acquired such a negative connotation that it was abandoned by the institution in the 1990s.

${ }^{54}$ Karl Deininger, Land Policies for Growth and Poverty Reduction: A World Bank Policy Research Report (World Bank 2003) 62; World Bank, Land Reform: Sector Policy Paper (World Bank 1975).

55 Deininger, supra $n 54$.

56 ibid 66.

57 ibid 68.

58 ibid 63.

59 ibid 28.

60 ibid 29.

${ }^{61}$ Elizabeth Fortin, 'Reforming Land Rights: The World Bank and the Globalization of Agriculture' (2005) 14(2) Soc Leg St 147, 170.

62 Elizabeth Fortin, 'Reforming Land Rights: The World Bank and the Globalization of Agriculture' (2005) 14(2) Soc Leg St 147, 170.
} 
by local populations as a fully-fledged management mechanism of natural and other CPRs, such as grazing lands, forests, water and fisheries. The commons may not merely represent an 'effective' way - in the economic sense - to ensure the management of shared natural resources; millions of small-scale farmers, pastoralists, forest-dwellers, artisanal fishers and indigenous peoples also depend on them for their livelihood. External development interventions in the form of individual land titling and privatization programmes, not only seem inappropriate where communal systems exist, ${ }^{63}$ but they may also destroy the traditional and communal way of life in developing countries. In this regard, the Commission on Legal Empowerment of the Poor (CLEP) ${ }^{64}$ pointed out the recurrent mistake of development actors, inspired by the 'tragedy of the commons', of transforming customary tenure and interests in commons, into private property rights, rather than registering these as the group-owned property of communities. ${ }^{65}$ Instead, the Commission recommended that '[t]he State should enhance the asset base of the poor by enabling community-based ownership' and that commons 'should be recognised and fully protected against arbitrary seizure'. ${ }^{66}$

The former UN Special Rapporteur on the Right to Food, Olivier De Schutter, in a 2010 report similarly observed that the formalization of property rights and the establishment of land registries may be the problem, not the solution: it may cause [herders, pastoralists and fisherfolk] to be fenced off from the resources on which they depend, making them victims of the vast enclosure movement that may result from titling'.67 The Special Rapporteur emphasized that 'while security of tenure is important and should be seen as crucial for the realization of the right to food, individual titling and the creating of a market for land rights may not be the most appropriate means to achieve it'. ${ }^{68}$ In his view, users' rights should instead be supported based on customary forms of tenure. He cited the examples of Kenya, where pastoralists were excluded from some land titling programmes, and Tanzania, where herdsmen had been deprived access to so-called 'unused' common grazing areas. To sum up, recognition of the commons by global economic policies and regulations is crucial for the latter's survival and legitimacy.

\footnotetext{
${ }^{63}$ Ana Palacio, 'Legal Empowerment of the Poor: An Action Agenda for the World Bank. To The attention of the President of the World Bank' (December 2005, revised March 2006) <http://siteresources.worldbank.org/INTLAWJUSTINST/Resources/LegalEmpowermentofthePoor.pdf> accessed 17 May 2018.

64 The Commission on Legal Empowerment of the Poor (CLEP) is an independent working group established in 2005, hosted by UNDP and co-chaired by former US Secretary of State Madeleine Albright and Peruvian economist Hernando de Soto. The Commission published its final report in 2008.

65 Commission on Legal Empowerment of the Poor, Making the Law Work for Everyone, Vol II (Commission on Legal Empowerment of the Poor and UNDP 2008) 83.

66 ibid 65.

67 United Nations General Assembly, 'Report of the Special Rapporteur on the right to food' (11 August 2010) UN Doc A/HRC/36/L.29, para. 25.

68 ibid para. 10.
} 


\section{International law to recognize the commons as a democratic practice of its own}

It is clear from the above that commons cannot survive in a policy and legal vacuum. They are 'social systems' that face a competitive struggle with capitalist and State domination in global (economic) governance. The commons serve as a new vocabulary that speaks to very diverse struggles of self-government against enclosures - from the rebellion of the Zapatista autonomous municipalities calling to recognize the integrity of their commons in Chiapa, Mexico, ${ }^{69}$ the 4000 acres of autonomous territory of the 'ZAD' ('zone à défendre') of NotreDrame-des-Landes in France ${ }^{70}$ to the citizen initiatives of the 'Commons Transition Plan' for the city of Ghent in Belgium. ${ }^{71}$ Together, these past and more recent experiences, at both local and global levels, for the preservation of both tangible and intangible resources, form what David Bollier called a 'silent revolution' against all forms of propertization and commodification. ${ }^{72}$ Other prominent public intellectuals such as Michael Hardt and Antonio Negri, ${ }^{73}$ David Harvey, ${ }^{74}$ Naomi Klein ${ }^{75}$ or Ugo Mattei ${ }^{76}$ have suggested that, since the commons empirically demonstrate that self-governance, far from being a utopian ideal, is and has long been a lived reality, the commons could and should be turned into the conceptual matrix of a new account of democracy. If one defines democracy as the institutional practice through which stakeholders deliberate and/or decide on the regulations that they are submitted to, the commons certainly represent direct forms of democracy.

We submit that international law could and should recognize and protect the commons as a democratic practice of its own. While international law certainly played a role in the vast enclosure of the commons, from the colonial era onwards, today it may very well constructively serve as a tool to combat the dispossession of communities around the world. However, the purpose is not to dismantle the idea of the commons by conceiving it in terms of vague and universal human rights language, thereby denying the concrete local and social distinctiveness of every single commons. Rather, our objective is to demonstrate that, pursuant to current international law, communities are entitled as a matter of legal rights to satisfy collective needs through the democratic self-management of commons.

In that respect, the project of a UN Declaration of the Rights of Peasants offers a window of opportunity for generalizing this model of community rights for all people involved in smallscale food production, including all those who depend on commons for their livelihood, beyond the distinct identities, cultures and ways of life of indigenous and tribal peoples. This new initiative follows a long-standing request of the international peasant movement, among which La Via Campesina (2016) and its Indonesian affiliated group Serikat Petani Indonesia, who denounce systematic human rights violations against peasants and other rural groups. Interestingly, one of the main factors triggering the international movement for peasants rights from Indonesia was the role the World Bank played in attempting to revise the Indonesian Basic Agrarian Law. From a strategic point of view, Indonesian farmers deemed international

\footnotetext{
69 See Kamala Visweswaran, Un/common Cultures: Racism and the Rearticulation of Cultural Difference (Duke University Press, 2010) 221; Gustava Esteva, 'Hope from the Margins' in David Bollier and Silke Helfrich (eds), The Wealth of the Commons: A World Beyond Market \& State (Levellers Press, 2012) p. xi.

70 'Zad For Ever, 'The Revenge Against the Commons' (24 April 2018) <https://zadforever.blog/2018/04/24/therevenge-against-the-commons/> (accessed 10 August 2018).

71 Stad Gent, 'A "Commons Transition Plan" for Ghent' (24 October 2017) < https://stad.gent/ghentinternational/city-policy-and-structure/ghent-commons-city/commons-transition-plan-ghent> (accessed 10 August 2018).

72 David Bollier, 'The Growth of the Commons Paradigm' in Charlotte Hess and Elinor Ostrom (eds.), Understanding Knowledge as a Commons: From Theory to Practice (MIT Press 2007) 27-40.

${ }^{73}$ Michael Hardt and Antonio Negri, Commonwealth (Harvard University Press, 2009) viii.

74 David Harvey, The New Imperialism (OUP 2003), 148.

75 Naomi Klein, 'Reclaiming the Commons' (2001) 9 New Left Review 91.

76 Capra \& Mattei, supra $n 30$.
} 
human rights action necessary to fight against the Bank's and other global economic actors' intervention in the liberalization of land regulations. ${ }^{77}$ In this trend towards the recognition of rights of peasants and their fight for food sovereignty, peasant and farmer groups started framing their demands in terms of new rights to commons, as this excerpt from the 2011 Declaration of the European Forum for Food Sovereignty shows:

Reclaiming the right to our Commons. We oppose and struggle against the commodification, financialisation and patenting of our commons, such as: land; farmers', traditional and reproducible seeds; livestock breeds and fish stocks; trees and forests; water; the atmosphere; and knowledge. Access to these should not be determined by markets and money. In using common resources, we must ensure the realisation of human rights and gender equality, and that society as a whole benefits. We also acknowledge our responsibility to use our Commons sustainably, while respecting the rights of mother earth. Our Commons should be managed through collective, democratic and community control. ${ }^{78}$

Following civil society pressure, in 2012 the UN Human Rights Council (HRC) established an open-ended intergovernmental working group with the mandate of negotiating a - non-binding - declaration, outlining the rights of peasants and other people working in rural areas. ${ }^{79}$ The 2018 UN Draft Declaration articulates a number of - implicit and explicit - guarantees for the protection of the commons, particularly relevant in the context of global (economic) governance, including the right of peasants to control their natural resources, to enjoy the benefits of their development, 'the right to have access to and to use the natural resources present in their communities that are required to enjoy adequate living conditions', 'the right to participate in the management of those resources' (Article 5); 'the right, individually and collectively, to the lands, water bodies, coastal seas, fisheries, pastures and forests that they need to achieve an adequate standard of living, to have a place to live in security, peace and dignity and to develop their cultures' (Article 17(1), emphasis added). ${ }^{80}$

The development of a UN Declaration on the Rights of Peasants is particularly noteworthy for this contribution, since it is arguably the first time that an international law document would expressly put forward a stand-alone obligation for States to recognize and protect the 'commons' as a governance model of its own. Article 17(3) of the Draft Declaration indeed includes a collective dimension of the 'Right to land and other natural resources':

States shall provide legal recognition for land tenure rights, including customary land tenure rights, not currently protected by law. All forms of tenure, including tenancy, must provide all persons with a degree of tenure security which guarantees legal protection against forced evictions. States shall recognize and protect the natural commons and their related systems of collective use and management (emphasis added). ${ }^{81}$

\footnotetext{
77 Heri Purwanto, 'Local To Global; How Serikat Petani Indonesia Has Accelerated The Movement for Agrarian Reform' in Henry Saragih (ed.), La Via Campesina's Open Book: Celebrating 20 Years of Struggle and Hope (La Via Campesina 2013) 3.

78 Nyéléni Europe, 'Food Sovereignty in Europe Now! Nyeleni Europe 2011: European Forum for Food Sovereignty' (21 August 2011) <http://www.nyelenieurope.net/sites/default/files/2016-06/NYELENI_Declaration_English.pdf> (accessed 22 May 2018) quoted in Priscilla Claeys, 'The Right to Land and Territory: New Human Right and Collective Action Frame' (2015) 75(2) Revue interdisciplinaire d'études juridiques 115, 123-124.

79 Human Rights Council (HRC), 'Promotion and protection of the human rights of peasants and other people working in rural areas', Resolution 21/19 (11 October 2012) UN Doc A/HRC/RES/21/19.

${ }^{80} \mathrm{HRC}$, 'Revised draft United Nations declaration on the rights of peasants and other people working in rural areas', Open-ended intergovernmental working group on the rights of peasants and other people working in rural areas, Fifth session (12 February 2018) UN Doc A/HRC/WG.15/5/2.

81 Note, however, that the official French translation of the 2018 Draft Declaration provides that 'Les États reconnaîtront et protégeront les ressources naturelles communes et les systèmes d'utilisation et de gestion collectives de ces ressources', which is not the same as 'natural commons' in English. The English term should
} 
The explanatory study on the rationale underlying the Draft Declaration prepared by the UN Office of the High Commissioner for Human Rights (OHCHR) indicates that this formulation 'highlights the importance of providing tenure security, including through the protection of customary tenure rights and the protection of commons, over the land, fisheries, forests, water and other natural resources on which peasants and other people working in rural areas depend for their livelihood'. ${ }^{82}$ This study defines the 'commons' by reference to the Oxford English dictionary as 'land or resources belonging to or affecting the whole of a community'. ${ }^{83}$

It is important to stress, however, that originally there was no specific reference to the term 'commons' in the very first draft presented by La Via Campesina and entitled 'Declaration of Rights of Peasants - Women and Men' ${ }^{84}$ It is only since 2016 and the proposal submitted by the Bolivian representative as chairperson-rapporteur of the working group that the Draft Declaration includes a reference to the commons. The reason why the draft now includes this term is to use as much as possible so-called 'agreed language' - that is to say, formulations to be found in other international human rights instruments, as well as other relevant international policy platforms.

The right to land in the current draft is, indeed, largely inspired by the Voluntary Guidelines on the Responsible Governance of Tenure of Land, Fisheries and Forests in the Context of National Food Security (Tenure Guidelines) ${ }^{85}$ adopted in 2012 by the Committee on World Food Security (CFS). The CFS is an intergovernmental and highly inclusive platform which is today authoritative in the field of world food governance. The Tenure Guidelines are the result of several years of negotiations among UN agencies, States, civil society organizations like La Via Campesina, the private sector, and the then UN Special Rapporteur on the right to food, Olivier De Schutter. The Guidelines seek to protect the access to food of the rural poor by recognizing different - formal or informal - models of shared natural resources governance at the local level, including the commons. Guideline 8.3 provides as follows:

$[T]$ here are publicly-owned land, fisheries and forests that are collectively used and managed (in some national contexts referred to as commons), States should, where applicable, recognize and protect such publicly-owned land, fisheries and forests and their related systems of collective use and management, including in processes of allocation by the State. ${ }^{86}$

In order to support the implementation of the Tenure Guidelines, the UN Food and Agriculture Organization (FAO) also prepared a series of technical guidelines, among which a publication entitled 'Governing Tenure Rights to Commons'. ${ }^{87}$ This document defines the 'commons' as natural resources such as land, fisheries and forests, which are used and managed collectively by 'a group of people (often understood as "community")'. ${ }^{88}$ Interestingly, like the Tenure

indeed be translated in French as 'communs naturels'. The French translation could therefore be subject to change in the future. HRC, 'Projet révisé de déclaration des Nations Unies sur les droits des paysans et des autres personnes travaillant dans les zones rurales', Open-ended intergovernmental working group on the rights of peasants and other people working in rural areas, Fifth session (12 February 2018) UN Doc A/HRC/WG.15/5/2.

$82 \mathrm{HRC}$, 'Normative sources and rationale underlying the draft declaration on the rights of peasants and other people working in rural areas', Study by the Office of the United Nations High Commissioner for Human Rights, Openended working group on the rights of peasants and other people working in rural areas, Fourth Session (15-19 May 2017) UN Doc A/HRC/WG.15/4/3, para. 240 (emphasis added).

83 ibid.

84 La Via Campesina, 'Declaration of Rights of Peasants - Women and Men' $<$ https://viacampesina.net/downloads/PDF/EN-3.pdf> (accessed 22 May 2018).

85 Committee on World Food Security (CFS), Voluntary Guidelines on the Responsible Governance of Tenure of Land, Fisheries and Forests in the Context of National Food Security (FAO 2012).

86 ibid, 12 (emphasis added).

87 Food and Agriculture Organization (FAO), Governing Tenure Rights to Commons: A guide to support the implementation of the Voluntary Guidelines on the Responsible Governance of Tenure of Land, Fisheries and Forests in the Context of National Food Security, Governance of Tenure Technical Guide No. 8 (FAO, 2016).

88 ibid, 52. 
Guidelines, this document refers extensively to international human rights treaties and declarations. ${ }^{89}$ From the start, it states that '[s]ecure tenure rights to commons are crucial for women and men' and that '[t]he Guidelines represent a historic opportunity to guide governments and hold them accountable in assuming their duties and fulfilling their obligations to implement secure tenure for the legitimate holders of rights to commons' ${ }^{90}$ As an expert of the working group on the UN declaration of peasant rights observed, the vision of the right to land promoted by the 2012 Tenure Guidelines is therefore 'very different' from 'the one that focuses on promoting individual property titles as the solution to secure land tenure'. ${ }^{91}$

Compared to the Tenure Guidelines, the current UN Draft Declaration on the Rights of Peasants represents a significant breakthrough in the process of recognizing the commons as a social system of its own in international law. Indeed, the UN Draft Declaration does not make the same mistake as the Tenure Guidelines, of assimilating commons to 'public' lands and resources. In the UN Draft Declaration, the term 'commons' is preserved, but instead is recognized as an institution for the management of shared resources - separate from, and beyond both public and private property.

After five years of work, the UN Human Rights Council has decided, during its $36^{\text {th }}$ session in September 2017 (with 34 votes in favour, two against - the United States and the United Kingdom - and 11 abstentions), that the open-ended intergovernmental working group would undergo its fifth and final round of negotiations from 9 to 13 April 2018, before the $38^{\text {th }}$ session of the Council in June 2018. Informal negotiations will continue in the meantime. Under strong pressure from the international peasant movement represented by La Via Campesina and NGOs - among which Centre Europe - Tiers Monde (CETIM) and FIAN International, the Declaration could be adopted by the Human Rights Council in September 2018 and then the UN General Assembly. If approved, and even if it falls under the category of 'soft law', the UN Declaration would represent an important step towards the international legal recognition of the commons - which peasants and other people working in rural areas have always used and controlled in order to secure their livelihood.

\section{Conclusion}

This contribution sought to address a social system that has been ignored for too long under international law: the commons. The great contribution of the American political economist Elinor Ostrom was to show that there are plenty of institutional arrangements which are formed by communities themselves and which often prove more effective than the typical 'all-public' and 'all-private' solutions in safeguarding commonly shared resources. Let us not neglect Ostrom's heritage. Land and natural resources in the Global South are often governed as commons - that is to say that their use, access and management is socially defined and organized in a collective and autonomous way, aside from the State and the market. According to a recent report by Oxfam, ILC and RRI, 2.5 billion people, including 370 million indigenous people, rely on communal land and natural resources around the world, which represent approximately 50 per cent of the global land mass. ${ }^{92}$ However, this collective model of bottom-

\footnotetext{
89 ibid, 13.

90 ibid, v.

91 Christophe Golay, 'Legal reflections on the rights of peasants and other people working in rural areas', Background paper, Prepared for the first session of the working group on the rights of peasants and other people working in rural areas (15-19 July <http://www.ohchr.org/Documents/HRBodies/HRCouncil/WGPleasants/Golay.pdf> accessed 22 May $2018,18$. 92 Oxfam, International Land Coalition, Rights and Resources Initiative, Common Ground. Securing Land Rights and Safeguarding the Earth (Oxfam 2016).
} 
up governance is still far from being accepted in global (economic) governance. Instead, echoing Garrett Hardin's 'Tragedy of the Commons', economic development actors like the World Bank still seem to assume that commons should be commodified and privatized to secure land tenure and ensure their transferability in markets. Because so many commons are based on traditional usage and customary practice, and are still considered 'backward' by development institutions, these communal systems tend to be highly vulnerable to State and corporate enclosure in the Global South. To date, only one-fifth of the communal lands around the world would be legally recognized..$^{93}$ This explains why local communities face the threat of being deprived from their most basic access to food, land and other essential resources.

Faced with this risk of enclosure of the commons in global (economic) governance, international law should provide tools and strategies to protect the commons. Admittedly, it remains difficult to foreground the notion of the commons in the international legal order as it stands. The ideas of open access and free-for-all exploitation of the global commons that are so entrenched in the discipline of international law, have very little to do with the self-governing practice of commoning according to ad hoc rules of access and use. Yet, it is possible to observe progressive developments in international and regional human rights instruments which recognize the commons as a social institution of its own. Even if its dominant conception probably remains statist and individualist in nature, international law may also be embraced 'from below' ${ }^{4}$ by civil society actors as a new guiding frame and weapon to save the commons in developing countries. International law may just represent yet another forum for contestation, but it is a new and significant one in the struggle for the commons. Not only traditional individual rights like the right to property have been interpreted by regional human rights courts in an evolutionary fashion to apply to groups and rights of use, but indigenous rights now also embrace a broader conception of the community rights of possession, occupation, use of land and other natural resources. These developments are likely to give legal recognition to commons-based institutions, with due respect to the autonomous rules of the communities concerned.

Most importantly, the project of a UN Declaration of the Rights of Peasants now puts forward, in its draft Article 17(3), a stand-alone obligation to recognize and protect the natural commons and their related systems of collective use and management. Interestingly, this initiative did not come from above, but was driven by civil society groups representing the peasant movement around the globe. Agrarian activist groups, such as Serikat Petani in Indonesia, decided to engage in the creation of a new collective right to the commons at the international level in order to push for social change and resist to their dispossession at the local level. Considering that peasants and rural workers represent 80 per cent of those suffering from hunger in the world today, the new attention given to the threats to this collective institution, through the UN Draft Declaration, is a welcome development. It suggests, for the first time, the existence of a window of opportunity for a new international human right to the commons. It now remains to be seen if the final Declaration will effectively respond to the legitimate demands of the world's poorest and most marginalized commoners - small-scale farmers, pastoralists, forest-dwellers, artisanal fishers and indigenous peoples who depend on commons for their survival. The human right to the commons cannot remain an empty promise: additional protection is urgently needed for the commons under positive international law.

\footnotetext{
93 ibid.

94 Balakrishnan Rajagopal, International Law from Below. Development, Social Movements and Third World Resistance (CUP 2003).
} 
The Leuven Centre for Global Governance Studies is an interdisciplinary research centre of the Humanities and Social Sciences recognized as a KU Leuven Centre of Excellence and as a Jean Monnet Centre of Excellence. It hosts researchers from law, economics, political science, history, philosophy and area studies. The Centre initiates and conducts interdisciplinary research on topics related to globalization, governance processes and multilateralism, with a particular focus on the following areas: (i) the European Union and global governance; (ii) human rights, democracy and rule of law; (iii) trade and sustainable development; (iv) peace and security; (v) global commons and outer space; (vi) emerging powers; and (vii) global governance and international law. It hosts the EU-China Focus and the Leuven India Focus.

In addition to its fundamental research activities the Centre carries out independent applied research and offers innovative policy advice and solutions to policy-makers.

In full recognition of the complex issues involved, the Centre approaches global governance from a multi-level and multi-actor perspective. The multi-level governance perspective takes the interactions between the various levels of governance (international, European, national, subnational, local) into account, with a particular emphasis on the multifaceted interactions between the United Nations System, the World Trade Organization, the European Union and other regional organizations/actors in global multilateral governance. The multi-actors perspective pertains to the roles and interactions of various actors at different governance levels, which includes public authorities, formal and informal international institutions, business enterprises and non-governmental organizations.

For more information, please visit the website www.globalgovernancestudies.eu

Leuven Centre for Global Governance Studies

Huis De Dorlodot, Deberiotstraat 34, 3000 Leuven, Belgium

Tel. ++3216328725

Fax ++32 16373547

info@ggs.kuleuven.be

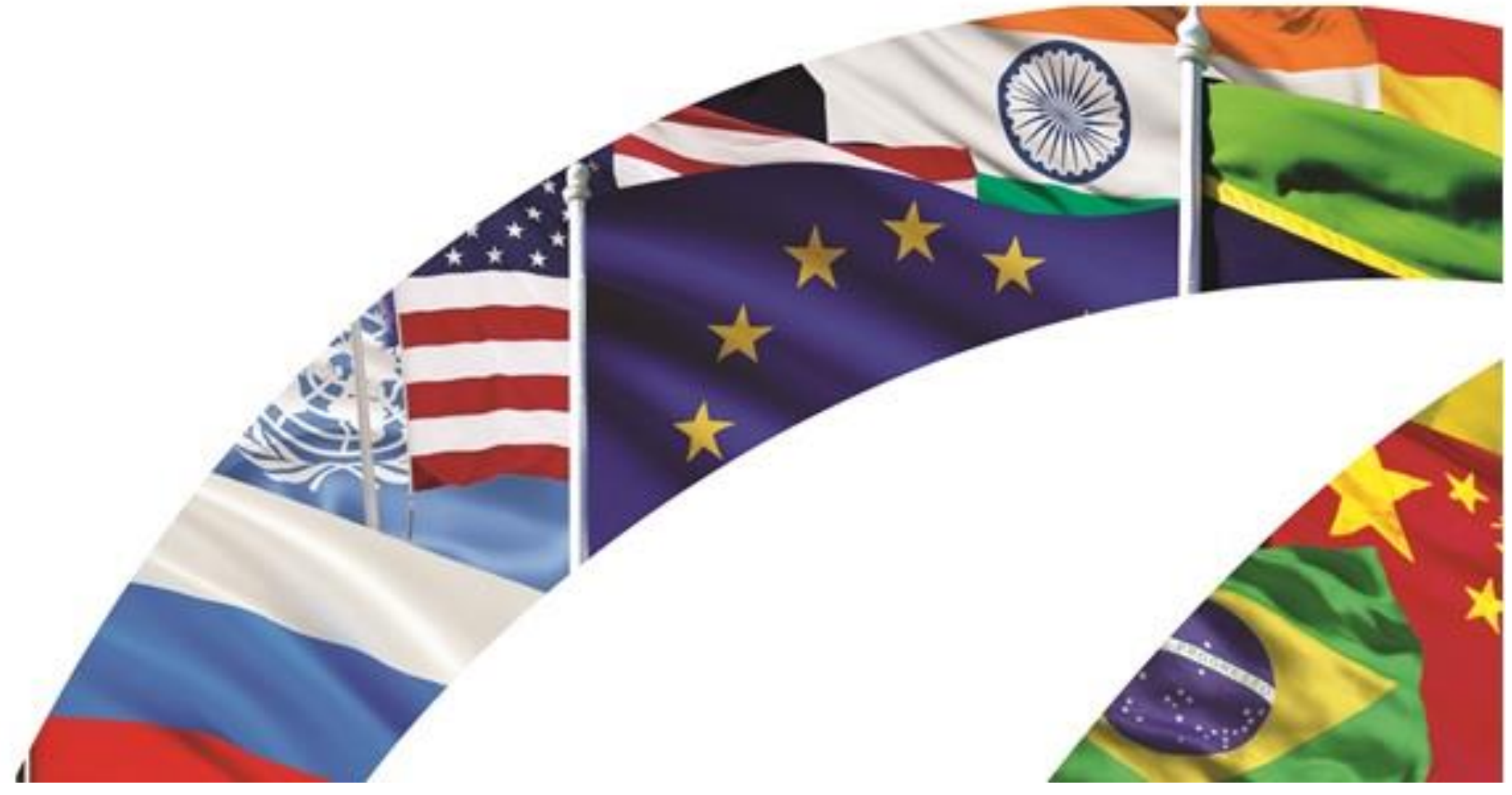

